\title{
Three-dimensional Ultrastructure of the Autonomic Nerve Terminals in the Lamina propria mucosae of the Rat Large Intestine*
}

\author{
Tatsuo UsHIKI \\ Department of Anatomy, Hokkaido University School of Medicine, Sapporo, Japan
}

Received February 11, 1992

\begin{abstract}
Summary. The three-dimensional ultrastructure of the autonomic nerve terminals in the lamina propria mucosae of the rat large intestine was studied by scanning electron microscopy using the $\mathrm{KOH}$-collagenase digestion method as well as by transmission electron microscopy. Observations showed unmyelinated nerves in the lamina propria mucosae as well developed just above the muscularis mucosae and forming a twodimensional irregular network by anastomosing with one another. Each nerve in the network consisted of axons and Schwann cells. The axons were about $0.1 \mu \mathrm{m}$ in diameter and had local swellings (about 0.2-0.5 $\mu \mathrm{m}$ diameter) along their course. Transmission electron microscopy revealed the presence of synaptic vesicles in these varicosities. Although some of the axons left the Schwann cell processes to run separately, most of them twined around or were embedded in the Schwann cell bodies or processes. Blind ends of axons were only occasionally observed in the nerve network. These findings suggest that the network of the unmyelinated nerves itself represents a terminal apparatus acting upon the muscular and glandular cells.
\end{abstract}

The structure of the autonomic nerve terminals was long one of the most disputed topics among classical light microscopists since CAJAL (1889) first reported the "interstitial cells" in the mucous coat of the silverimpregnated intestine; some investigators considered that the autonomic nerves formed a network of anas- tomosing interstitial "neurons", while others stated that the nerve terminals comprised a syncytial network of Schwann cells with "neurofibrils" (see review by BoEKE, 1949; KAPPERS, 1964; KoBAYASHI, 1990).

Modern light microscopists using histochemical methods, however, clarified that the autonomic nerve endings are composed of varicose nerve fibers containing such chemical transmitters as noradrenaline and acetylcholine (GABELLA and CosTA, 1968; SILVA et al., 1971). These findings gave us the idea that the transmitters are released "en passage" from varicosities of these nerve fibers. Transmission electron microscopy (TEM), on the other hand, has revealed that the autonomic nerve fibers in the terminal region are small bundles of unmyelinated axons containing numerous synaptic vesicles. These previous findings, however, seem to be inconsistent at several points and the entire shape of the autonomic endformation remains to be clarified. Recently some authors have studied the autonomic nerve terminals of several different tissues by scanning electron microscopy (SEM) (TACHIBANA et al., 1985; ENDO and KOBAYASHI, 1987; USHIKI and IDE, 1988a). These observations are, however, still fragmentary and insufficient; the overall morphology of the autonomic nerve terminals as well as their relationship to effector cells need to be depicted more precisely in three dimensions.

Keeping these problems in mind, the present study is undertaken with the aim to clarify the threedimensional ultrastructure of the autonomic nerve

\footnotetext{
*This paper is dedicated to Professor Emeritus K. TANAKA on the occasion of his retirement from Tottori University School of Medicine.

This study was supported in part by a Grant-in-Aid for Scientific Research (No. 03770001) from the Ministry of Education, Science and Culture, Japan
} 
terminals in the lamina propria mucosae of the rat large intestine by SEM. The present study used a $\mathrm{KOH}$-collagenase digestion method in order to remove the surrounding connective-tissue elements from nerve fibers. This method was originally developed by MILLER et al. (1982) for SEM observations of vascular smooth muscle cells, and our modification of this method has proven applicable to SEM studies of the three-dimensional cytoarchitecture of nervous elements in various tissues (USHIKI and IDE, 1987; 1988b).

\section{MATERIALS AND METHODS}

Adult male Wistar rats weighing $180-250 \mathrm{~g}$ were used in the present study. The animals were anesthetized by intraperitoneal injection of pentobarbital sodium (Nembutal, $50 \mathrm{mg} / \mathrm{kg}$ body weight), and perfused through the left ventricle with physiological saline and then with a fixative containing $2 \%$ paraformaldehyde and $2.5 \%$ glutaraldehyde in $0.1 \mathrm{M}$ cacodylate buffer ( $\mathrm{pH}$ 7.4). The colon was then removed, cut into short loops and immersed in the same fixative over one day at room temperature.

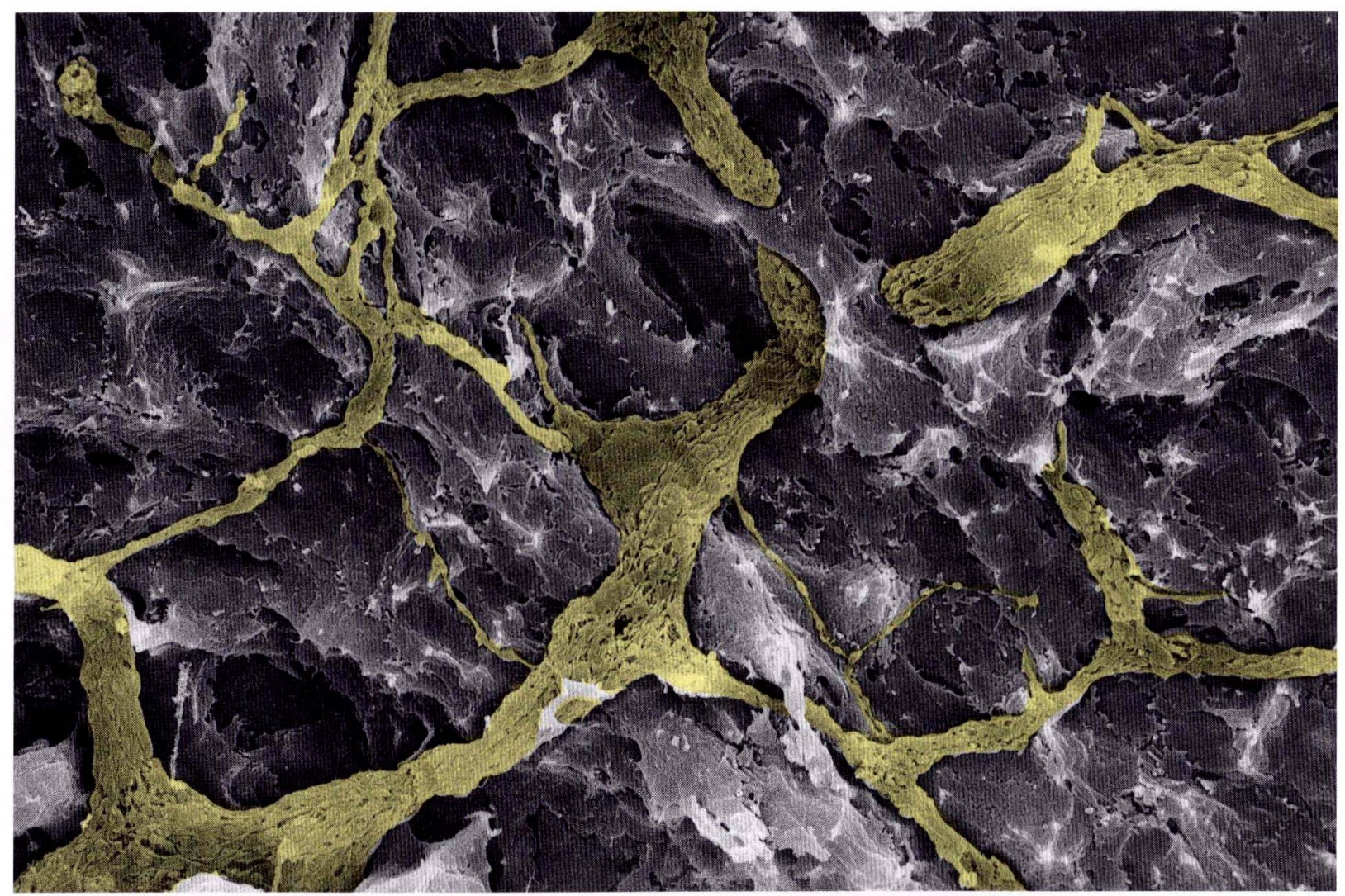

Fig. 1. Scanning electron micrograph showing an overview of the mucosa of the rat large intestine treated with the KOH-collagenase method. Since the crypts have been removed with forceps, subglandular nerves (colored in yellow) are clearly found against the background of the lamina muscularis mucosae. These nerves vary in diameter and repeatedly branch and anastomose, forming a two-dimensional network just above the muscularis mucosae. $\times 2,100$

Fig. 2. Closer view of anastomosing nerve cords in the subglandular nerve network. These cords are composed of varicose axons (green) and Schwann cell processes (yellow). $\times 9,500$

Fig. 3. High magnification of Schwann cell body (yellow) in the subglandular nerve network. Axons (green) are found on the surface of the Schwann cell body. The arrow indicates a bifurcation of an axon. $\times 8,500$ 

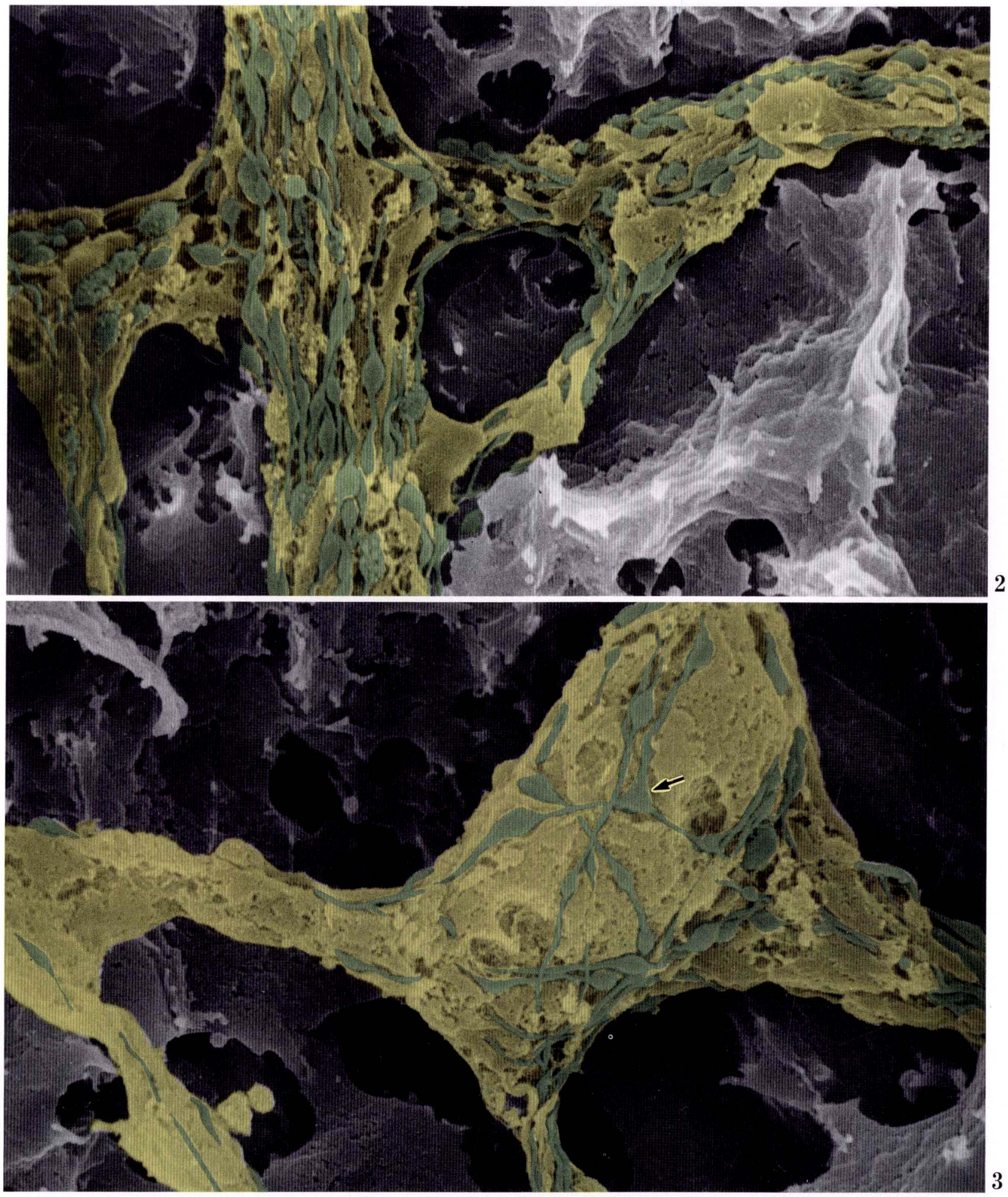

Figs. 2 and 3. Legends on the opposite page. 
To remove the connective tissue elements of the colon, the specimens were treated according to our KOH-collagenase digestion method (USHIKI and IDE, 1987 ; 1988b) as follows: after being rinsed several times in $0.1 \mathrm{M}$ phosphate buffer ( $\mathrm{pH} 7.4$ ), the specimens were placed in $5 \mathrm{~N} \mathrm{KOH}$ for about $8 \mathrm{~min}$ at $60^{\circ} \mathrm{C}$. They were then washed in $0.1 \mathrm{M}$ phosphate buffer ( $\mathrm{pH}$ 6.8) and immersed in collagenase solution (Sigma, type II, about $1 \mathrm{mg} / \mathrm{ml}$ in $0.1 \mathrm{M}$ phosphate buffer, $\mathrm{pH}$ 6.8) for $3-5 \mathrm{~h}$ at $37^{\circ} \mathrm{C}$. These digested tissues were washed in the buffer solution or distilled water and conductive-stained by MURAKAMI's tannin osmium method (1973); that is, the tissues were put in a aqueous solution of tannic acid for $2-3 \mathrm{~h}$, rinsed in distilled water for more than one hour, and stained with $1 \% \mathrm{OsO}_{4}$ solution for several hours at room temperature. They were then dehydrated through a graded series of ethanol, transferred to isoamyl acetate and critical point-dried using liquid $\mathrm{CO}_{2}$. The dried tissues were then dissected with a needle and forceps under a binocular dissecting microscope and were mounted on aluminum stubs with double-sided tape. They were then coated with platinum in an ion coater (Eiko IB-5, Eiko Engineering Co.), and observed in a SEM (Hitachi HSM-2B or S-430) at an accelerating voltage of $15 \mathrm{kV}$.

For the TEM study, specimens fixed in the same manner as above were postfixed for $2 \mathrm{~h}$ with $1 \% \mathrm{OsO}_{4}$ solution in cacodylate buffer $(\mathrm{pH}$ 7.4), dehydrated through a graded series of ethanol and embedded in Epon 812. Ultrathin sections were stained with uranyl acetate and lead citrate, and observed in an electron microscope (Hitachi H-800).

\section{RESULTS}

The present KOH-collagenase method clearly removed connective tissue matrices with no significant damage to the cell surface of the digesed tissues. Under a binocular microscope, the intestinal glands of these specimens were removed successfully from the underlying tissues with sharpened needles and forceps. Thus, subglandular nerves in the lamina propria mucosae were broadly observable against the background of the lamina muscularis mucosae (Fig. $1)$.

The subglandular autonomic nerves comprised a network of unmyelinated nerve cords developed just above the muscularis mucosae. These nerve cords varied in width from 0.3 to $5 \mu \mathrm{m}$; thick ones were of a flat tape-like shape, while thin ones were cord-like in shape. They crept along the muscularis mucosae in various directions and often anastomosed with one another to form a two-dimensional irregular network, which was apparently closely associated with the smooth muscle cells of the muscularis mucosae.

Each nerve cord in the network consisted of axons and Schwann cells (Figs. 2, 3). The axons were about $0.1 \mu \mathrm{m}$ in diameter and had local swellings along their course. These varicosities were eliptic or spindle-shaped, ranging from $0.2-0.5 \mu \mathrm{m}$ along their shortest diameter, and from $0.4-1.3 \mu \mathrm{m}$ along their longest diameter. TEM revealed the presence of the synaptic vesicles in thicker axons, which probably correspond to the varicosities (Fig. 4). The intervaricose distance was variable, ranging from 0.5 to more than $3 \mu \mathrm{m}$. These axons were roughly bundled with the Schwann cell processes; most of axons were not completely covered by the Schwann cell processes but were exposed on the surface of the nerve cords (Fig. 2). The neighboring axons in these regions often closely contacted each other. At the portion where Schwann cell bodies were present, axons ran twining around the cell bodies like a creeping plant (Fig. 3). Bifurcation of axons was often found along their course. Blind ends of axons were occasionally observed in the nerve cords.

Most of very thin nerve cords branching from the thick ones were composed of a single axon associated with a fine process of the Schwann cell (Fig. 5). However, some of the thinnest nerve cords consisted only of a single axon apart from the Schwann cell processes, and were often closely associated with smooth muscle cells of the muscularis mucosae (Fig. 6). Blind ends of these single axons were also found, though they were small in number (Fig. 7).

Figure 8 shows a schematic drawing of the auto-

Fig. 4. Transmission electron micrograph showing a transverse section of an unmyelinated nerve in the subglandular nerve network. Schwann cell cytoplasm $(S)$ incompletely encloses several axons. Note an axon (arrow) containing synaptic vesicles. $\times 18,500$

Fig. 5. Scanning electron micrograph of a thin nerve cord consisting of a varicose axon and an associated process of the Schwann cell. $\times 18,000$

Fig. 6. A varicose axon (arrowheads) leaving a thick nerve cord $(N)$. This axon is independent of the Schwann cell processes. $\times 9,000$

Fig. 7. A blind end of a singly coursing axon. $\times 12,500$ 

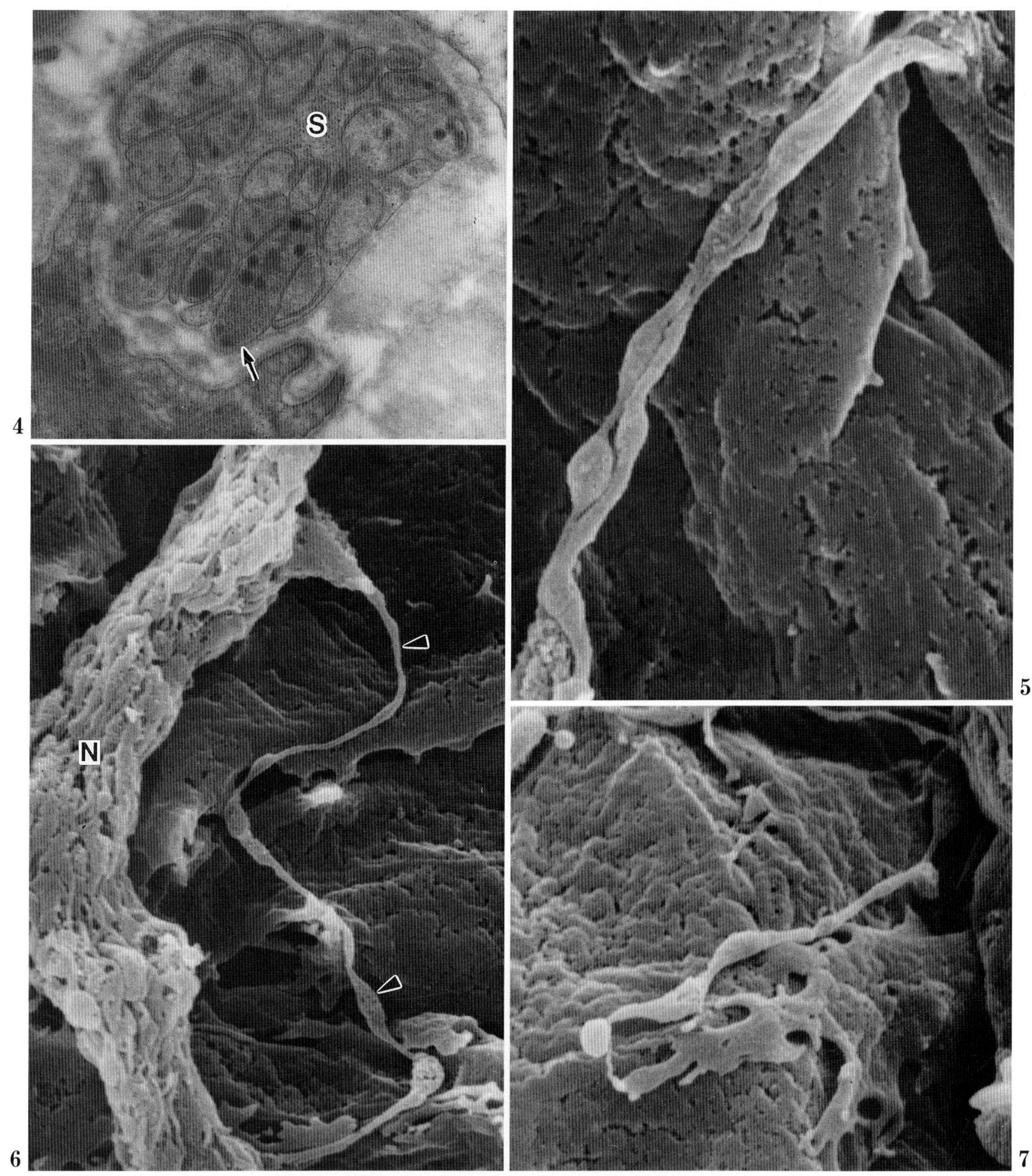

Figs. 4-7. Legends on the opposite page. 


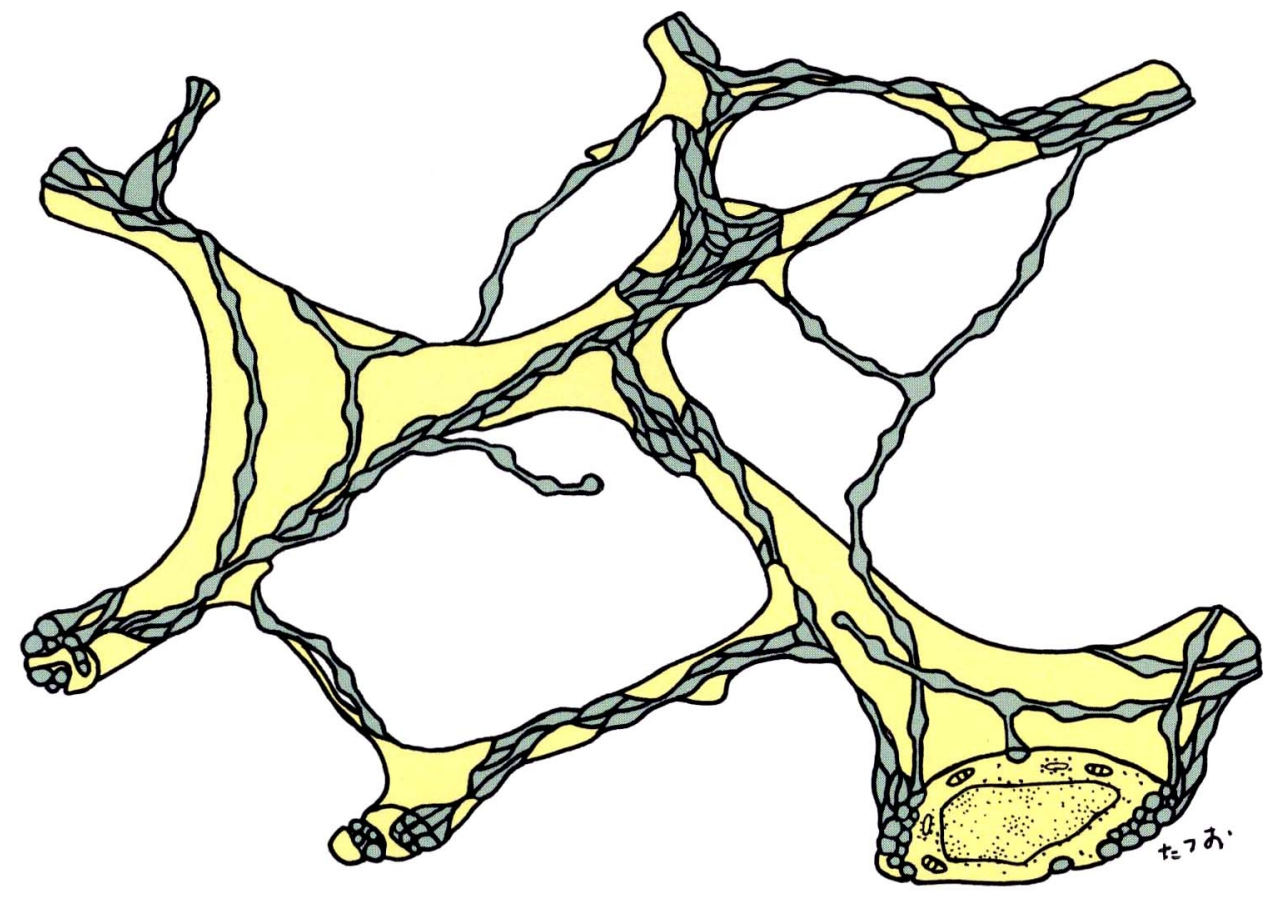

Fig. 8. A schematic drawing of the three-dimensional structure of the autonomic nerve terminals in the lamina propria mucosae of the rat large intestine. The autonomic nerve terminals form a network of anastomosing nerve cords. These cords consist of varicose axons (green) twining around or embedding in the Schwann cell bodies and processes (yellow). Note the presence of bifurcations and blind ends of axons.

nomic nerve terminals as revealed in the present study.

\section{DISCUSSION}

The three-dimensional structure of peripheral nerves has been previously studied by SEM after removal of connective tissue components and basal laminae using $\mathrm{HCl}$-digestion, $\mathrm{HCl}$-collagenase, or trypsin- $\mathrm{HCl}$ digestion methods (e.g., UEHARA et al., 1981; DESAKI and UEHARA, 1981; TACHIBANA et al., 1985; ENDO and KoBAYASHI, 1987; USHIKI and IDE, 1988a). These methods, however, were complicated and sometimes gave inconsistent results such as the incomplete removal of extracellular matrices and occasional disruption of the cell surface. To overcome such technical problems, we recently proposed the application of a KOH-collagenase method to the SEM observation of peripheral nerves (USHIKI and IDE, 1987, 1988b). The present study has used this method for observing the autonomic nerves and succeeded in demonstrating the three-dimensional ultrastructure of the auto- nomic nerve terminals more clearly and precisely than before. The $\mathrm{KOH}$-collagenase method seems to have advantages over previously employed methods for the elimination of connective tissue elements in SEM specimens, and is expected to be useful for SEM studies of the three-dimensional cellular organization of nervous elements in various tissues.

In his light microscopic studies of Golgi-silverimpregnated specimens, CAJAL first reported characteristic triangular or spindle-shaped cells which projected their varicose processes to form a nerve network in the mucous coat of the mammalian small intestine (CAJAL, 1889, 1893, 1911). He considered these cells to be primitive neurons intercalated between the post-ganglionic axons and the effector cells. Since then, the presence and nature of these cells, the "interstitial cells of Cajal", have been discussed by a great number of light microscopic investigators (see review by BOEKE, 1949; KAPPERS, 1964; THUNEBERG, 1982; KOBAYASHI, 1990): some authors supported CAJAL's statement and thought that the autonomic nerve terminals consisted of a network of the interstitial "neurons" of Cajal (LAWRENTJEW, 1926; SCHA. 
BADASCH, 1930), while others declared these cells to be Schwann cells (STÖHR, 1957; HillaRP, 1959) or a special type of connective tissue cell (KNOCHE, 1952). Electron microscopists, on the other hand, clearly showed that the autonomic nerve terminals comprise unmyelinated axons bundled by Schwann cells, but ignored the presence of the interstitial cells of Cajal in the mucous coat. The present SEM study, however, has clearly shown that no interstitial cells except the Schwann cells are present in the terminal network of the autonomic nerves in the mucous coat. Because the interstitial cells described by CAJAL coincide in location and reticular extension with the terminal Schwann cells, these two are probably the same structure. Extremely thin (about $0.1 \mu \mathrm{m}$ in diameter) axons embedded in the Schwann cells could be easily misinterpreted under the light microscope as "neurofibrils". These findings correspond well to those obtained in our previous studies of the rat pancreas (USHIKI and IDE, 1988a). The results of the present study also support the idea proposed by KOBAYASHI and his colleagues (ENDO and KoBAYASHI, 1987; KOBAYASHI et al., 1989) in their light and electron microscopic studies of the guinea pig small intestine, where they stated that the interstitial cells identified by the Golgi silver-impregnation methods are a "chimera" or cellular amalgamation consisting of Schwann cell bodies and extremities of axons.

Thus, it is evident that the autonomic nerve terminals form a network of nerve fibers consisting of axons and associated Schwann cells. Since the varicose axons are not completely covered by Schwann cells but are exposed in many places on the surfaces of the nerve cords, it is reasonalble that the nerve network itself represents a terminal apparatus of the autonomic nerves in the intestinal mucosa. In his light microscopic studies using methylene blue and other certain staining methods, HILLARP (1959) observed a similar network of autonomic nerves in organs such as the uterus and iris, and considered these networks to be directly superimposed on all effector cells to form an innervation apparatus in various organs. Our findings strongly support HILlARP's concept of the autonomic innervation apparatus.

The present study has also provided further new information on the fine structure and arrangement of the axons as well as their relationship with both Schwann cells and the effector cells. One of these findings is the presence of the axonal branching in the network. This finding may indicate that each axon itself ramifies to form a network in the terminals. Therefore, one axon probably innervates a large percentage of the muscle cells in an "en passage" manner.
Another remarkable finding in the present study is that a few axons are completely independent of and apart from terminal Schwann cells. Similar findings were reported by TACHIBANA et al. (1985) in their SEM studies of the urinary bladder in the guinea-pig. These axons are often closely associated with the muscle cells and seem to directly innervate the target cells. These singly coursing axons are, however, interpreted a morphological variation of nerve cords in the terminal network.

The present study has also demonstrated the presence of blind ends of axons in the network, although ENDO and KOBAYASHI (1987) observed no true ends of any axonal processes in the mucous coat of the guinea-pig small intestine. Because these structures are scarce, they, unlike those in the motor endplates, do not seem to play a specially important role in innervating the target cells.

Several investigators have reported the presence of the B-afferent neuronal processes in the intestinal mucosa (MeI, 1978; SATo and Koyano, 1987). Whether these afferents are present or not in the terminal network seems to be an important question for understanding the mechanism of visceral sensation. This is, however, still unelucidate in the present study.

Acknowledgements. The author wishes to thank Prof. K. ABE, Hokkaido University School of Medicine, for his generous encouragement and support throughout this study.

\section{REFERENCES}

BoEke, J.: The sympathetic endformation, its synaptology, the interstitial cells, the periterminal network, and its bearing on the neurone theory. Discussion and critique. Acta Anat. 8: 18-61 (1949).

CAJAL, S. R. Y: Nuevas aplicaciones del metodo de coloracion de Golgi. Sobre la red nerviosa ganglionar de las vellosidades intestinales. Gaceta Med. Catal. 12: 614616 (1889).

: Sur les ganglions et plexus nerveux de l'intestin. C. R. Soc. Biol. Paris 5: 217-223 (1893).

- Histologie du système nerveux de l'homme et des vertébrés. Maloine, Paris, 1911.

DESAKI, J. and Y. UEHARA: The overall morphology of neuromuscular junctions as revealed by scanning electron microscopy. J. Neurocytol. 10: 101-110 (1981).

Endo Y. and S. KobaYashi: A scanning electron microscope study on the autonomic groundplexus in the lamina propria mucosae of the guinea-pig small intestine. Arch. Histol. Jap. 50: 243-250 (1987).

Gabella, G. and M. Costa: Adrenergic fibers in the mucous membrane of guinea-pig alimentary tract. Experientia 24: 706-707 (1968). 
Hillarp, N.-A.: The construction and functional organization of the autonomic innervation apparatus. Acta Physiol. Scand., Suppl. 157: 1-38 (1959).

KAPPERS, J. A.: A survey of different opinions relating to the structure of the peripheral autonomic nervous system. Acta Neuroveg. 26: 145-171 (1964).

KNoche, H.: Über die feinere Innervation der Arteria uterina des Menschen. Zugleich ein Beitrag zum Bau der neurovegetativen Endformation. Z. Zellforsch. 37: 205-239 (1952).

KobaYASHI, S.: The structure of the autonomic end apparatus in the guinea-pig small intestine and the problem of the interstitial cells of Cajal. Acta Med. Biol. 38: 103127 (1990).

Kobayashi, S., J. B. Furness, T. K. Smith and S. Pompolo: Histological identification of the interstitial cells of Cajal in the guinea-pig small intestine. Arch. Histol. Cytol. 52: 267-286 (1989).

LAwRENTJEW, B. J.: Über die Verbreitung der nervösen Elemente (einschließlich der "interstitiellen Zellen" Cajals) in der glatten Muskulatur, ihre Endigungsweise in den glatten Muskelzellen. Z. Mikrosk.-Anat. Forsch. 6: 467-488 (1926).

MEI, N.: Vagal glucoreceptors in the small intestine of the cat. J. Physiol. 282: 485-506 (1978).

Miller, B. G., R. I. Woods, H. G. Bohlen and A. P. Evan: A new morphological procedure for viewing microvessels: a scanning electron microscopic study of the vasculature of small intestine. Anat. Rec. 203: 493503 (1982).

MuraKami, T.: A metal impregnation method of biological specimens for scanning electron microscopy. Arch. Histol. Jap. 35: 323-326 (1973).

Sato, M. and H. Koy ano: Autoradiographic study on the distribution of vagal afferent nerve fibers in the gastroduodenal wall of the rabbit. Brain Res. 400: 101-109 (1987).

Schabadasch, A.: Intramurale nervengeflechte des Darmrohrs. Z. Zellforsch. 10: 320-385 (1930).

Silva, D. G., G. Ross and L. W. Osborne: Adrenergic innervation of the ileum of the cat. Amer. J. Physiol. 220: 347-352 (1971).
STöHR, P: Mikroskopische Anatomie des vegetativen Nervensystems. In: (ed. by) W. von MöllendoRfF and W. BARGMANN: Handbuch der mikroskopischen Anatomie des Menschen, IV/5. Springer, Berlin, 1957 (P. 1-678).

Tachibana, S., M. Takeuchi and T. Fujiwara: Visualization of autonomic varicose terminal axons by scanning electron microscopy. J. Electron Microsc. 34: 136138 (1985).

Thuneberg, L: Interstitial cells of Cajal: intestinal pacemaker cells? Adv. Anat. Embryol. Cell Biol. 71: 1-130 (1982).

Uehara, Y., J. Desaki and T. FuJiwara: Vascular autonomic plexuses and skeletal neuromuscular junctions: a scanning electron microscopic study. Biomed. Res. 2 (Suppl.): 139-143 (1981).

Ushiki, T. and C. IDE: Scanning electron microscopic studies of the myelinated nerve fibres of the mouse sciatic nerve with special reference to the Schwann cell cytoplasmic network external to the myelin sheath. J. Neurocytol. 16: 737-747 (1987).

- Autonomic nerve networks in the rat exocrine pancreas as revealed by scanning and transmission electron microscopy. Arch. Histol. Jap. 51: 7181 (1988a).

: A modified $\mathrm{KOH}$-collagenase method applied to scanning electron microscopic observations of peripheral nerves. Arch. Histol. Cytol. 51: 223232 (1988b).
Dr. Tatsuo UsHikI

Department of Anatomy

Hokkaido University School of Medicine Kita-15 Nishi-7, Kita-ku Sapporo, 060 Japan 